UDC 327::911.3(44:497.7)

DOI: https://doi.org/10.18485/iipe_ria.2021.72.1181.2

Biblid 0543-3657, 72 (2021)

Vol. LXXII, No. 1181, pp. 23-42

Original paper

\title{
FRANCE'S GEOPOLITICAL VISION FOR EUROPE AND THE WESTERN BALKANS: THE CASE OF NORTH MACEDONIA
}

\author{
Toni MILESKI ${ }^{1}$ \\ Katerina KLIMOSKA ${ }^{2}$
}

\begin{abstract}
The main aim of the paper is to analyse France's position in a global and regional geopolitical context. That also means in EU affairs related to enlargement policy and views about the Western Balkans and North Macedonia. The European Union is modelled on the spread of democratic values and economic benefits for the members. Also, the EU has recently developed sustainable neighbourly policies. Nevertheless, recent events like Brexit, misunderstandings within the Union, and the enlargement process blockade led to deconstructive processes and opened up new dilemmas that require comprehensive scientific analysis. The paper aims to analyse France geopolitically and its influence on the Western Balkans and the EU enlargement policy. The changing methodology of the EU approaching stopped North Macedonia and Albania in 2019. We will try to research and provide a solution for North Macedonia, considering the new aspect of its foreign policy and France's possible role in that process. From a theoretical point of view, this paper is based on critical geopolitics, i.e., a practical geopolitical approach. Primarily, the authors used articles and online data as a source of analysis.

Keywords: France, Geopolitics, North Macedonia, Western Balkans, Macron.
\end{abstract}

\section{INTRODUCTION}

The history of intensive French involvement in the Balkan questions could be dated to 1854 when the Great Powers fought in a war for the first time since

\footnotetext{
${ }^{1}$ Full Professor at the Ss. Cyril and Methodius University in Skopje, Faculty of Philosophy Department of security, defence and peace. E-mail: toni@fzf.ukim.edu.mk

${ }^{2} \mathrm{PhD}$ candidate at the Ss. Cyril and Methodius University in Skopje, Faculty of Philosophy Programme on International relations and conflict management. E-mail: katerina.klimoska@yahoo.com
} 
Napoleon. Ironically, this war, the Crimean War, which was condemned by historians as a meaningless problem that could have been entirely avoided, was not started by Russia, Britain or Austria - countries with interest in the Eastern Question, but from France.

In 1852, the French emperor Napoleon III, who had just come to power through a coup, persuaded the Turkish sultan to give him the nickname Protector of Christians in the Ottoman Empire, a role that the Russian tsar had traditionally kept to himself. Nicholas the First was angry that Napoleon, whom he considered an illegitimate ruler and novice, continued to interfere in Russia's role as protector of the Balkan Slavs and demanded equal status with France. When the sultan ousted the Russian envoy, Russia severed diplomatic relations (Kissinger 1994).

Historically analysed, the Balkans has never been France's primary foreign policy interests. However, Paris's diplomacy, especially since the 19th century, was forced to pay some attention to the region, especially Germany, Austria-Hungary, Russia and Turkey. Paris has established privileged relations with Serbia, which were specially strengthened during the First World War, for example, with the appearance of the French Army of the Orient (Armée d'Orient) in this part of Europe. After 1918, the French leadership believed that a centralised and united federal state had a stabilising effect in the Western Balkans, which was ethnically and religiously mixed. After the Second World War, the country's eccentric thirdparty policy led by Tito was rather positively appreciated by French governments, but with some reservations.

After the collapse of the Berlin Wall and the process of the dissolution of Yugoslavia in the early 1990s brought back to Paris, for a brief period, a distinctly pro-Serbian political orientation. In that period, French lawyer Robert Badinter led the so-called "Badinter Commission" to resolve Yugoslavia's dissolution. From North Macedonia perspectives, it was interesting that the "Badinter commission" ruled that two Republics, Macedonia and Slovenia, fulfilled all the conditions for recognitions based on previously formally requested recognition by the European Community and its Member States. In the case of Croatia, a reservation was expressed concerning the rights of minorities. The request for recognition made by Bosnia-Herzegovina was refused (Pellet 1992).

In the next period, Croatia's recognition and Slovenia's independence triggered a heated debate between Germany and France. Mitterrand demanded guarantees for Belgrade, while Chancellor Helmut Kohl required rapid recognition. Finally, Yugoslavia's dissolution gained international recognition, while the internal latent ethnic conflict escalated into a Yugoslav war. In 1995, France's military presence in the Balkans was increased and gave impetus to the Dayton Agreement on the Bosnia-Herzegovina issue. It is no coincidence that the peace treaty concluding the first phase of the Yugoslav Wars was signed on 14 December 1995, in Paris's 
Elysée Palace. However, after 1989, Paris had no particular long-term strategy for the region. The main objectives were general: eliminating the hostilities, promoting the democratic system of the states created by the dissolution of Yugoslavia and the long-term European integration of the countries.

Continuously, France believed the region would automatically catch up with Europe without playing a significant role, and these countries were not a priority for French politics. Paris, referring to its past friendship, only displayed some prejudice towards Serbia (IFAT 2020). However, in the so-called effective bilateral relations, it was only modest, even if excellent relations were demonstrated in 2001 during Jacques Chirac's official visit to Belgrade. One year after the summit held in Zagreb between the European Union and the Balkans, an event took place where the French President expressed faith in support of the European integration of the former Yugoslav Member States. At the Thessaloniki Summit in 2003, France argued that the Western Balkan' small states were due to join the European Union. Paris repeatedly expressed its support for Serbia's efforts to join the European Union after 2008 and did not prevent Croatia from joining in 2011. However, in reality, the friendly, encouraging statements were followed by only a few concrete actions. The French President attended the Balkans Summit in Ljubljana in 2013, supported the launch of the Berlin Process in 2014, and hosted the event in Paris in 2016. However, any significant turnarounds in France's politics for the Western Balkan countries did not follow these spectacular meetings. With respect to European enlargement in the Balkans, French diplomacy has always been constrained and reluctant. France did not openly obstruct the accession process, but it insisted on adherence to accession conditions (Fejérdy 2020).

Searching and interpreting actual political moments after the new approaching methodology in the EU in 2019 may sound very confusing. The authors of this article think that it is a prominent and temporarily determined path for starting the accessing process. North Macedonia and Albania are affected by the new methodology. Montenegro and Serbia, which have already started the process with an old methodology, can choose how they will continue. Using the appropriate methodology, we will try to determine France's role in the new geopolitics of the EU after Brexit. Does North Macedonia have a chance for prompt integration in the EU? We will try to establish France's position in the new EU and decide whether it is a beginning of new great France (as in Napoleon time) or Macron's doctrine is oriented into strengthening the whole EU.

Regarding the methodology, this article uses a holistic approach and dominantly uses the methodology of critical geopolitics. That means the composition of mainly practical geopolitical analysis and comparative, legal, and analytic methods. The main emphasis in terms of the data analysis method is set on discourse analysis. This method is appropriate because critical geopolitics sees 
geopolitics as discourse (O’Tuathail and Agnew 1992). We will draw upon both speeches of President Macron and French foreign policy practices during his presidency. Evermore, if we use Fairclough's approach, we will find that it is appropriate for our research. According to Fairclough, discourse analysis is a form of argumentation that involves more practical argumentation. Argumentation for or against specific modes of action and argumentation that can ground decisions (Fairclough and Fairclough 2012). With the help of discourse analysis, we will try to analyse Macron's rhetorical and symbolic forms by explaining his politics and justify the exercise of France's power in the public eye. In this case, towards Europe and the Western Balkans, and especially North Macedonia's negotiation path to the EU. We are analysing Macron's language and the context of the language used in his speeches.

Relying on the extensive literature on critical geopolitics, the authors predominantly consulted the following literature: O’Tuathail 1996; O’Tuathail and Dalby 1998; O’Tuathail et al. 1998; Mamadouh 1998; O’Tuathail 1999; Kelly 2006; Agnew 2013; and Haverluk et al. 2014.

It is clear that in the last 100 years, geopolitical critiques have also developed in parallel with geopolitics. What can be noticed is the fact that the critique of geopolitics was very little represented in public by the geopolitical ideas themselves. This may partly explain the consistency and rigidity of particular geopolitical views that have survived to the present day. However, certain things have changed considerably in both the political and historical spheres. The existence of criticism is significant for several reasons. One of the reasons is that the justification for international conflicts, as a rule, was found in the geopolitical and geostrategic constellations of relations. There has been criticism of such approaches, of those who have taken and justified such actions, but its arguments have not convinced states of the need for a different, nonviolent action. The second reason is that it is necessary to develop different modern geopolitics approaches to overcome the dangerous tendencies to simplify geopolitics (O’Tuathail, 1999, 107-124).

The authors of the article choose the practical geopolitical analysis because foreign relations decision-makers who rely on practical geopolitics generally use practical and pragmatic inference. This is an appropriate methodological approach for research in this paper because practical geopolitical thinking relies more on the everyday context than on the geopolitical tradition. To provide a working conceptualisation of geopolitical vision as a central analytical tool in the paper, we will focus on the possibilities of creating a strong Europe as a geopolitical player through which France would differentiate itself as a leader. 


\section{FRANCE IN THE ERA OF MACRON PRESIDENCY AND GLOBAL GEOPOLITICS}

Emmanuel Macron is the eighth president of the Fifth Republic of France. He launched the movement «En Marche!», founded on 6 April 2016, and was its leader until his victory in the presidential election on 7 May 2017, beating the opposite candidate Marine Le Pen. What has President Macron done for the fifth Republic of France?

In a short time, France's international position has strengthened. Following the practical geopolitical approach, we found that France's geopolitical perspectives and vision were explained in Macron's speech delivered at the Sorbonne in 2017 and at the Ambassadors Conference held in Paris in August 2019, and much better explained in the new Macron's doctrine from 2020.

In 2017, Macron spoke at the Sorbonne about achieving unity within the European Union and the importance of its reorganisation. His speech focused, among other things, on explaining the idea of more European Union rings with different degrees of integration. This idea was coldly received in European circles, especially in the eastern part of the European Union. However, the aspiration for a different European Union architecture has strengthened after Brexit and Great Britain's exit from the Union. In short, Macron's plan was a sovereign, united and democratic Europe. Macron stressed in his speech that the time has come when France makes proposals to drive Europe forward, and for every European who wishes to do so - the time has returned. He referred to Robert Schuman, who was, according to his words, brave enough to suggest founding the European Union in Paris on 9 May 1950. "A unified Europe was not accomplished, and we had war", he said emphatically (IE 2017).

At the Ambassadors Conference held in Paris in August 2019, according to Macron, the international order was undermined in an unprecedented way, with massive disruption happening in almost every region and on a monumental scale, likely for the first time in our history. Above all, there was a transition, a change in geopolitics and strategy. He went on to state, "We are most certainly witnessing the end of Western hegemony over the world". He argued that since the 18th century, we had become used to an international order focused on Western hegemony. The Enlightenment most likely influenced French hegemony in the eighteenth century, British hegemony in the nineteenth century, thanks to the Industrial Revolution, and American hegemony in the twentieth century, thanks to two major conflicts and that power's economic and political dominance. Macron noted that things were changing and that they have been deeply affected by the mistakes made by Westerners in specific crises. He emphasised American decisions over the last several years, which did not start with the Trump administration. But these decisions "have led us to re-examine certain 
involvements in conflicts in the Middle East and elsewhere, and to rethink fundamental diplomatic and military strategy and on occasion elements of solidarity which we thought were forever inalienable even though we had developed them together during periods of geopolitical significance, which have however now changed. Moreover, it is also the emergence of new powers whose impact we have probably underestimated for far too long" (AC 2019).

Macron continued with the constatation that major upheaval risk was increased twofold thanks to geopolitical and military turmoil. "We live in a world where the number of conflicts is rising, and I see two key risks," he said (AC 2019). "The first is that these wars are becoming more aggressive and causing a rise in civilian casualties. Take a look at the different theatres of operations around the world. And the second thing is that the world has started to become more savage, and here again the order on which our convictions and our systems were sometimes based is disappearing. In innocence and silence, we are abandoning the arms control treaties that emerged at the end of the Cold War. All that should raise far-reaching questions. First, it should make us see that our habits and information are no longer valid. And then that should prompt us to examine our strategy because the two nations that now hold the real cards in this affair are the Americans and the Chinese" (AC 2019).

Macron described the strategy of boldness and vision. It is about trying to rediscover something that profoundly characterises the French spirit and restore European civilisation. Macron believes that this should be their goal at home, in European strategy and internationally. The French spirit is a spirit of resistance with a universal calling. "Having a spirit of resistance means one does not give in to fate or adapt to things and habits. It means believing that we can prevail when things are unjust by giving ourselves the resources to succeed and the reforms to make us stronger, we can rebuild our economic muscle and productivity. We can make things happen. We do not accept the prevailing order for good reasons, and we succeed in rediscovering our deep-seated values" (AC 2019). He believes that the thing that has always characterised Europe, the unifying thread in our mission, is true humanism. He says this because it is no longer apparent. Moreover, if we take the easy road and continue to see the world in the way it is shaping up to be, and as he described, this European humanism will disappear.

France's diplomacy is also intense because it has a strong army, a strong state, and Macron thinks it is essential that they should continue to reflect on themselves. Macron wants France intense diplomacy to work towards the strategic goal: regain control over France destiny in a rapidly changing world and to give its people back some of the control they are owed and breathe new life into the European civilisation project to which France has contributed politically, strategically, culturally, and in terms of imagination (AC 2019). 
If we approach analysing the Macron doctrine (Le Grand Continent 2020), we could conclude that his view on the future is going towards "more Europe" and "much stronger Europe". Here we point to his idea for the "Paris consensus", which will be built on ideological and practical work (sides), both on making political Europe and its geopolitical character. Europe as a critical geopolitical player on the chessboard, on one side, and also the transformation of our contemporary economics where we face "uncontrolled increase of inequality", on the other side. The touch of the French geopolitical school (human geopolitics) we also see in his key priority in this consensus, which would be a "rephasing" at the global level around the environmental priority - "a realistic ecology". In his doctrine, among the words, ideas and goals he wants to achieve, we hear the very sophisticated "voice" of French geopoliticians from the past. We refer here to Elisée Reclus's: L'homme est la nature prenant conscience d'ellemême" (Reclus 1908). This doctrine could be seen as a defender of European values. These shared values make this diversity of countries with their different cultures and histories possible to succeed in a shared home called Europe. Macron is mentioning the "European sovereignty", but very shy. So, at this moment, he talks about "European strategic autonomy", which should be built in terms of defence (military), technology, and law. When it comes to Europe's borders, Macron is reaching way beyond the current EU borders, so he talks about the Balkans in his vision, but only as reformed states with European values. At the Sofia Summit in 2018, he said: "I am in favour of anchoring the Balkans in Europe and moving towards Europe. But I think we need to look at any new enlargement with a lot of prudence and rigour". Again, here, he reaffirmed what we could read in his vision for Europe - France will only support expansion with new countries members when there is first "a deepening and a reform of our Europe", but also when reforms are taken in the Balkan countries (concerns about crime, corruption and governance in the region) (Financial Times 2018), which will be evaluated without hypocrisy or lax. At some moments, in putting out the structure of his doctrine where he defined Europe in these broad terms, a parallel could be made with a few French politicians: De Gaulle, who viewed historical and geographical Europe "from the Atlantic to the Urals" "Oui, c'est l'Europe, depuis l'Atlantique à l'Oural, c'est l'Europe, c'est toute l'Europe, qui décidera du destin du monde!" (de Gaulle 1959) as a way of increasing the power of the countries of the continent, and Europe as a key geopolitical player; Jean Monnet, for whom the European community was a market that would one day be a source of political power; it was therefore open to the whole continent; and on the other hand, Robert Schuman who stood on that it should only bring together countries that resembled each other (Foucher 2016). We can conclude that Macron's doctrine is made as a collage of French academics and politicians' 
influence from the past, incorporated with Macron's original intellectual capacity in an original plan for Europe.

\section{FRANCE AND EU ENLARGEMENT IN THE WESTERN BALKANS}

Researching many scientific articles (Smith 2017; Ker-Lindsay et al. 2017; Economides 2020), we can conclude that enlargement is in the EU's "DNA". Indeed, accession of new member states was on the European agenda since the European Economic Community's creation in the 1950s. The accession of the UK and the countries that eventually formed with it the European Free Trade Association had already been under discussion. So was Greece and Turkey's association - with a perspective of accession. Since then, consecutive enlargements have brought EU membership from 6 to 28 (27 after Brexit in 2020) and have almost incessantly been on the EU agenda. Axel Sotiris Walldén argues that enlargement is enshrined in the Union's charters since the Rome Treaty. The enlargement clause establishes accession to the EU as a quasi- "right" of democratic European states, not as a mere option for the incumbent member states. True, there is no legal right of accession: a state can apply to become a member, but the Union is not obliged to accept the application. Besides, the requirement for democracy incorporates the well-known "criteria" for membership. Based on these criteria, the member states assess each candidacyalbeit with considerable margins of interpretation (Walldén 2017).

Enlargement policy rapidly degenerated during the last decade. Today, it is practically at a standstill in all three dimensions, the Western Balkans, Turkey and European neighbouring countries. We can assume this as a negative development, both for the EU and its neighbours. The revival of the policy is conditional upon a necessary, but an improbable, significant shift in the EU's strengthening solidarity. The aim of our paper is the Western Balkans and France's politics about EU enlargement.

We will start with the constatation that the Western Balkans is a part of Europe, geographically surrounded by the EU Member States. As part of one continent, the citizens of Western Balkans and the citizens of EU member states share the history and cultural heritage, which has established links that hold them in common until today. The President of the European Commission, Jean Claude Juncker, in 2017, reaffirmed the European future of the Western Balkan countries. He noted, "If we want more stability in our neighbourhood, then we must also maintain a credible enlargement perspective for the Western Balkans" (EC COM[2018] 65 final). The EU enlargement strategy for the Western Balkan countries foresees technical and financial support measures to ensure and safeguard the region's stability, foster economic development, and support the 
region's countries' smooth accession process. Core issues such as the rule of law, fundamental rights, strengthening democratic institutions, public administration reform, and economic development and competitiveness remain key priorities in the enlargement process. Besides, regional co-operation and good neighbourly relations are essential for progress on the countries' respective European paths. After the Berlin Summit organised by France and Germany, held in 2019, the Office of President of France Emmanuel Macron published the "French Strategy for the Western Balkans" (France Diplomacy 2019). At its core, again, we find the same postulates on which Macron is building his political strategy, so he stipulates few main goals towards the Balkans: economic and social, security, justice and defence. Although this is a bilateral approach of France towards the Balkan countries, he again stays faithful to his European dream. In this strategy, he added that "France's strategy aims to support and complement the European Union's work to support the region's convergence with Europe". The strategy is in line with the new methodology for enlargement, seeking tangible results, especially in the mention fields. With this, the Balkans in Macron's Europe's vision could not be denied, but with significant preconditions and explicitly fulfilled preconditions.

Suppose we are framing power politics and traditional forms of geopolitics, alluding to concepts such as spheres of influence as negative aspects of European history, leading to world wars. It is then evident that the EU needs to claim a higher moral ground in promoting soft forms of geopolitics as normativity in international relations. In the last five years, in the EU policy makers' vocabulary, we have seen the rise of the traditional aspects of geopolitics. However, to promote its principles and standards, the EU strives to advance its interests abroad. It can be understood as a softer version of geopolitics, where space is important. However, the fundamental goal of the $\mathrm{EU}$ is to extend its spatial principles and values as a way of advancing its foreign policy (Nitoiu and Sus 2019). That kind of reasoning is mainly understood through critical geopolitical thinking.

What kind of interest does France, however, have in the process of EU enlargement? In this regard, Natasha Wunsch argued that France's reluctant stance on EU enlargement towards the Balkans represents a wider ambivalence between the French establishment and the citizenry towards the European project. Wunsch $(2017,11)$ in her analysis states: "Despite its moral support for EU membership of the Balkans, France is no major player in the EU when it comes to defining the Union's long-term approach towards the region. Instead, the country tends to align itself with Germany's positions on the dossier, stepping forward only in rare cases of divergences, such as on the question of opening accession talks with Serbia. Expertise and human resources dealing with the Balkans are limited both within and outside the French institutions, reflecting a 
lack of national strategic interest in the region. The awareness that no enlargement will occur in the coming years confirms France in its perception that there is no need to increase its investment levels, be it material or in terms of human resources, in the Balkans. Over the next years, France is likely to keep its spot on the backbench, neither supporting enlargement too vocally nor actively hindering the Balkan countries' progress towards eventual membership".

Recently, the situation has changed. A new Methodology is arising, and the role of France is smoothly changing. After the non-decision on EU enlargement at a European Council meeting in October 2019, France faced a fierce attack by many EU politicians, academics, think tanks, and external actors. However, the question remains whether the attack was justified, or France played a crucial role in guaranteeing the EU's stability. It is known that even during the recent EU enlargement with the country members as Romania, Bulgaria and Croatia, the general conclusion is that the methodology under which EU enlargement is implemented does not provide satisfactory results, and a new approach must be established. In particular, in this regard, issues concerning the rule of law, the judiciary, corruption and administration are critical and add disappointment in the older EU members. Serbia and Montenegro are the countries that have already started EU accession negotiations. Serbia in 2013 and Montenegro in 2012. Unfortunately, no particular improvement in these two countries' everyday lives could be identified since the start of negotiations with the EU up to date.

Concretely, the EU faces a rift over enlargement policy after French "non" during the October 2019 summit. Due to that reason, the EU polity is currently going through an intense period of contestation and challenge. To distance itself from the French "non", the EU Parliament adopted a resolution on 24 October 2019. It expressed regret and deep disappointment over the EU's failure to agree on opening negotiation talks with North Macedonia and Albania. This issue clearly demonstrates that enlargement was shifted in its political dimension from the geopolitical arena to the domestic one.

Nevertheless, what the Non-Paper means and how it is positioning France in the EU enlargement policy? Lalatović describes this question in a transparent way. She notes that the Non-paper is described as an attempt by Paris to justify its prior position. According to some authors, it has delivered "a heavy if not mortal blow to the EU's credibility in its nearest neighbourhood". This view suggests that the mentioned French position has increased doubt among the Western Balkan countries on their future EU prospects and, in a way, pulled the drag on EU enlargement policy. Also, it is stated that it seriously undermined some of the core EU principles and values. Such as the principle of legal certainty - that in a way predetermines a moment when a country "deserves a certain dose of appreciation" of its efforts invested in the EU accession negotiation process. All of this proves that the current accession methodology is not an autonomous 
process, but rather a technocratic procedure in single-member states' hands, given the right to veto. Some more optimistic views suggest that outlined changes in the negotiation procedure with the Western Balkan countries could allow aspiring countries to efficiently adapt to the EU rules before entering the bloc's institutions. In the same tone, these interpretations support the thesis that Macron's Non-paper reflects "unequivocal support" for the EU membership drives of the countries from the Western Balkans under the condition they are able to overcome some significant challenges facing nowadays that require "the profound political, economic and social transformations [...] that continue to be too slow and the concrete benefits for citizens in candidate countries remain insufficient" (Lalatović 2020).

The postponing of the decision about the start of EU accession talks with North Macedonia and Albania was a surprise, but for some was expected. Namely, the group consisting of France, the Netherlands and Denmark can be described as a group of EU members in favour of the controlled enlargement. It is of great importance for them, especially for France, that the candidate countries start the negotiations fully prepared in order not to cause further problematisation of the EU institutions' functioning and the EU project. However, the assumption is that these EU countries were not alone in this approach at the Summit in 2019, so the uncertainty about decisionmaking may have also been a question to some other EU members. Nevertheless, what is important to note and has been abused at the time? No one at the Summit has used the rhetoric of "No to enlargement" or stated that the enlargement is "dead". France was determined that the enlargement methodology first has to be changed to make a decision. Consistent with his position, French President Macron, on the meeting with Plenković, the Croatian Prime Minister, at the beginning of 2020, reiterated the same - continuing the enlargement with a changed methodology. France has put forward its proposal as a possible solution.

In November 2019, the French Non-Paper to reform the European Union accession process was presented. The French non-paper begins with the words: "we reaffirm our unequivocal support to the European perspective of the Western Balkan countries". It is further pointed out that the Balkan countries historically, culturally and geographically belong to Europe. This dismisses the attacks, pointing France opposition to enlargement as groundless. According to France, the new approach to enlargement should be based on four principles: gradual association, stringent conditions, tangible benefits and reversibility (Politico 2019). When considering each of the steps proposed in the French proposal, it can be concluded that it is all in the function of producing real benefits of the enlargement process for the citizens of the candidate countries and ensuring a real implementation of the reforms to be taken until the final accession in the EU. This way, both sides benefit: candidates, especially the citizens, get reformed 
systems alike European one, with improved quality of life; while the EU is assured that having a fully-fledged new member state in the future could not cause significant new turbulence in the EU structure. How EU enlargement has unfolded, so far, can be described as bureaucratic without a more significant impact and a substantial influence on the processes taking place in the EU candidate countries, and thus without particular impact on ensuring a real reform of the candidate country's system. Another aspect in favour of the new methodology and the French position is one which offers a comparison of the old process of enlargement by which North Macedonia was getting ten positive annual reports from the EU Commission and on the other hand, no remarkable improvements in the range of real-life in terms of the rule of law and democracy: in Democracy Index 2019 Macedonia is defined as a hybrid regime (Economist 2020), by Freedom House is recognised as "partly free" (Freedom House 2020). That is why the French proposal for more robust political governance is more than welcome. This way, the EU Commission and the EU members would review the evaluations, and the role of the Council would be strengthened. Contrary to what one would like to point out, the French proposal is not for halting enlargement or drastically altering the current enlargement process, but for improving it and benefiting the EU and the EU candidate countries.

Europe faces numerous challenges. From Brexit (for the first time an EU founder leaves the EU.), the rise and impact of populist parties in the EU, the problems of climate change, the fight against terrorism, the protection from external influences in undermining the EU project, the influence of the United States of America, China, Russia. We live in the time of the 4th Industrial Revolution. Europe has a problem with the rule of law in some of its members and faces social riots from its Demos that demand more and better from the EU politicians. Therefore, the European Union cannot afford the comfort of recklessness in geopolitical steps in any sphere of its activity, even in the field of enlargement. The issue of EU borders is not closed since not all countries that are part of geographical Europe are formally part of the European family. Of course, the completion of this issue is of great geopolitical importance for the structure of Europe, for protection of external influence and their possible impact on the EU project, as well for the safety of its borders. However, that must be done with extreme caution. If we view through the eye of the German geopolitical school, we say that the goal of taking up more space through EU enlargement is justified.

Nevertheless, if we look from the French geopolitical school point about space and expansion, it is essential to focus on the human aspect. Planning strategies only from a purely geopolitical point of view have proved inadequate for both the reality of the 21 st century and the EU project's nature. Therefore, towards a geopolitical approach, we must also use a critical geopolitical 
approach. That is to say, we must have in mind that the EU project is one of its kind, and there is a danger if the wrong philosophy leads it. The EU is a family of states with their history, culture, and customs, united under the crown of agreed common values based on unity: the rule of law, democracy, human rights and good governance. Lack of respect for the shared values on which the EU family is based, whether it is a Member State or a candidate country, is always a sign of a potential problem in the EU in the future. So, it is not a question of excluding certain countries, but of being able to deliver effective policy which will promote common values, principals and interests. Additionally, the current situation in the EU with no clearly defined borders and difficulty in agreeing on EU's limits contributes to the slow and challenging enlargement process.

In his Non-paper, Macron remained fateful to his Initiative for Europe about a sovereign, united, democratic Europe. In his Sorbonne speech, he noted they fully respected the acquis and democratic requirements. This EU "will have to open itself up to the Balkan countries because our EU is still attractive, and its aura is a crucial factor of peace and stability on our continent". In Macrons words, "They will have to respect the conditions stipulated, but securing them to a European Union reinvented in this way is a precondition for their not turning their backs on Europe and moving towards either Russia or Turkey or towards authoritarian powers" (FRSch 2017). That does not currently uphold European values, after what Macron added: "If we can accept this demanding enlargement, it is also because the European Union's stronger foundation will allow more effective differentiation forms". So, in his ambitious plan for Europe, even in 2017, Macron was very clear about where and how he sees Europe based on shared values, respected by all member countries, and refers to candidate countries. He sees Balkan countries as part of Europe, "our Continent" as he says, but with fulfilled preconditions. In his video message addressed to Macedonia's citizens before the referendum, back in 2018, he says that he firmly believes that this agreement is fair, quote: "for you, the whole region and Europe". A significant segment of this video addressing Macedonians is that he does not mention the enlargement process or connecting Prespa with Macedonian negotiations for the EU. He expresses his position but underlying that the decision to change the name and constitution is up to Macedonia citizens. Here again, we see his credibility regarding his strategic plan for Europe, as our continent has common values.

After the Bulgarian veto, French Minister for Europe Clement Beaune was interviewed by Le Grand Continent in 2020. He concluded that North Macedonia and Bulgaria could not agree on the origin of the Macedonian community. He said, "We are obsessed with history, yet this should not be synonymous with refusing the future" (Le Grand Continent 2020). Again, France is putting aside the matter with questions that are not part of the Copenhagen 
criteria, and their primary stress is about the fulfilment of basic European principles and values. In Macron last interview for the same geopolitical group from Paris, speaking about Macron's doctrine (Le Grand Continent 2020), he mentioned "strengthening and structuring political Europe", "strong and political Europe", "reinvent the useful form of co-operation", "modernise our structure"," build a much stronger Europe, the voice, strength and principles of which can carry weight in this reformed framework". So, we can say that Macron's objection and demanding new methodology before the enlargement process is carried on are part of his bigger idea for Europe, reformed stronger and united.

\section{THE MACEDONIAN CASE}

Although there is still debate over the boundaries of Europe, there is not a question of whether but when and how countries that are part of geographical Europe will also be part of the European Union. North Macedonia is situated in Southeast Europe, on the Balkan Peninsula, surrounded by the Republic of Serbia, the Republic of Albania, Kosovo*3, the Republic of Bulgaria and the Republic of Greece. It is a small country, but the importance of its geopolitical position is high. This country's importance lays in its central position on the road to Europe. However, we can call it The Gate to and off Europe, on the way out of Europe. The Republic of North Macedonia got its first positive EU Report and recommendation from the EU Commission to start the negotiation on 14 October 2009. For 11 years, North Macedonia is receiving positive Reports and recommendations from the Commission to start the negotiation. The reason, as many say, was the name dispute with Greece. In September 2018, a Referendum was held in the Republic of Macedonia about the so-called Prespa Agreement. The referendum was not successful. However, the Prespa Agreement was passed through State institutions, implemented in the Constitution, and the name dispute was closed. However, it was not just Greece; Bulgaria came up with its demands; an Agreement with Bulgaria was made. Today, the country is facing a veto from Bulgaria. The Republic of North Macedonia was an excellent example of the Balkan for many years. Macedonia deserved opening the negotiations with the EU ten years ago, even more than today.

Nevertheless, politics always came over the law somehow in this case. Let us say that EU enlargement is based on accession criteria or the Copenhagen criteria in Western Balkan plus a unique process with three aims, "Regional cooperation". It is not evident on which criteria are based these disputes over the name, history, culture and one country as in the Macedonian case. So, we cannot

\footnotetext{
${ }^{3}$ Not recognized by Serbia.
} 
see the usual European principals in this matter. The EU stepped out from its framework in the Macedonian path to the EU, which brought uncertainty and new problems to the enlargement process and ruined the EU's geopolitical plans.

In which geopolitical circumstances Macedonia tries to open the negotiation process? There are identified several geopolitical obstacles determining the gloomy period of the EU enlargement process. The recently finished Brexit and the ongoing Covid-19 pandemic era are also negative geopolitical factors that followed up the monetary crisis that began in 2008. Therefore, the EU enlargement process's general context is not very easy. Namely, the internal crisis within the Union regarding the Belarus embargo, new Union budget or a resolution on human rights in China should be considered when analysing each candidate country's accession from the Western Balkans region. Another relevant context is the regional framework for the Balkan countries' accession (Gasmi and Prlja 2020). The region needs more vital co-operation for the joint development of the regional infrastructure, trade, cohesion policy, and bilateral relations between individual countries of the Western Balkans, which have recently deteriorated significantly. Doing so would highlight the Western Balkans shared common values, such as multiculturalism, natural resources, tourism capacities, and cohesion. One valuable attempt to enhance regional co-operation was when Serbian President Vučić established the so-called Mini - Schengen area in the region. However, only North Macedonia and Albania joined this Serbian initiative through the agreement. Such failure had a negative impression on the rest of the region, i.e., that Mini - Schengen was meant to be a substitute for an EU membership (Gasmi and Prlja 2020, 70).

Regarding the above, Professor Michal Vit for "Euractive" did an interview where the assumption for future enlargement is not seen by 2030. He noticed, "The whole Western Balkans region will be de facto integrated into that economic part, as this will be in the interests of the EU's key economic actors". However, politically, in his opinion, "it is impassable for someone to come up with an initiative at the moment that values, culture, identity will frame, it will not work" (Plevák 2021).

\section{CONCLUSION}

We can conclude that Europe is at the core of the French strategy. Europe accompanies Macron in his language, whether used in his speeches or written down. Thinking of France, he is also reflecting on Europe. Europe as a common home, but a strong Europe as a precondition for the stronger France. This is the approach for the Balkan, too. He is taking France back to the Balkan, but step by step, with the demands of tangible and relevant results and all in the name of stronger Europe. Never before, since Napoleon and De Gaulle, has France been 
at the centre of policy and strategy building in Europe and widely in the world (the relevance of this paper is Europe). Since 2017, Macron has brought back the spirit of what it means to be European. However, no one can deny that he did that with language messages delivered. And without any doubt, he is dedicated to spreading this idea on the Balkan. In the future, we should expect the German practical geopolitical approach to be switched with the French political, human geopolitical approach, seeking more Europe.

Although the borders of Europe are not defined yet, France has not put a line with which they wrote off the Balkans. Since De Gaulle's time and his view on geographical Europe, or Jean Monnet's Europe's openness to the whole continent, today's Macron's effort for more involvement at the Balkan is written down in his Initiative for Europe. The New approach in the enlargement process is needed to assure the process's credibility and transform candidate countries into European ones. At the moment, we see the lack of that. With this, the new methodology proposed by France is justified. France is pro enlargement, but a controlled one with fulfilled preconditions.

Summing it up, we could say that Macron's strategy follows the thread of the French geopolitical school, i.e., care for nature, climate, human rights and values at the centre of his geopolitical planning. It is quite logical that such an approach is used towards enlargement. We can also assume that in the next period, the question would be whether the emergence of Macron suppresses the German classical geopolitical approach. At the expense of human and critical geopolitics, Europe will begin to build its profile as a geopolitical player on the chessboard under French impact.

From North Macedonia's perspective, one gets the impression that we have been turned into a geopolitical laboratory. On the way to the EU, we have to accept everything, mostly to our detriment. Something that is not provided in the basic directions and preconditions for EU membership. We will point out several possible scenarios to bring sound conclusions and forecasts for what awaits North Macedonia on the enlargement process's path.

Scenario 1. The European Union is moving from the principle of unanimity towards a qualified majority in decision-making in enlargement. This way, if North Macedonia starts to reform itself with significant results, it will be a good argument for the EU member states about the country's capacity to fulfil the requirements stipulated in the new methodology for enlargement. The process towards the EU for North Macedonia will be opened, with a qualified majority. Here we expect France to be pro-vocal on the issue only if the Country candidate delivers any significant results and the EU project's reform has started.

Scenario 2. Membership in the European Economic Area (EEA), for economic benefit, but without political unity. A long pause in the enlargement 
process at least up to 2030, meanwhile strengthening the European neighbourhood policy that does not involve accession, offered privileged partnerships. In this scenario, France would be pro. Engagement with its Francophonie and Agency for development and other state and non-state actors are expected from France.

Scenario 3. Without serious EU efforts to integrate the Western Balkans, the region is moving towards Chinese hegemony. Pandemic and crisis of US democracy have shown us that the West does not democratically renew itself. A various analysis shows the possible transition to at least a binary US-China hegemony, and China hegemony in the long run.

Scenario 4. Stagnation of the enlargement process and putting the Balkan countries in limbo, with an option for a "mini-Schengen" area. Here is expected France to engage itself with its Francophonie and Agency for development as a support of the countries and building the French influence.

Scenario 5. The comeback of US diplomacy at the Balkan, helped by the German diplomacy, brought back the so-called "bulldozer diplomacy" and closed the open disputes on the Balkan, but with possible adverse effects, in the long run, the EU project. The German geopolitical philosophy of "more land" and US Kissinger's approach vis-a-vis French geopolitical philosophy "human in the centre". In this scenario is not expected significant involvement of France.

\section{REFERENCES}

[AC] Ambassadors' conference - Speech by M. Emmanuel Macron, President of the Republic. 2019, August 27. https://lvambafrance.org/Ambassadorsconference-Speech-by-M-Emmanuel-Macron-President-of-the-Republic

Agnew, John. 2013. "The origins of critical geopolitics". In: The Ashgate Research Companion to Critical Geopolitics, edited by Klaus Dodds, Merje Kuus and Joanne Sharp, 19-32. London: Routledge.

[EC] European Commission. 2018. A credible enlargement perspective for and enhanced EU engagement with the Western Balkans, COM (2018)65 final, Communication from the Commission to the European Parliament, the Council, the European Economic and Social Committee and the Committee of the Regions. February 6. https://ec.europa.eu/info/sites/info/files/ communication-credible-enlargement-perspective-western-balkans_en.pdf

Economides, Spyros. 2020. From fatigue to resistance: EU enlargement and the Western Balkans. Hertie School and London School of Economics and Political Science: The Dahrendorf Forum.

Economist. 2020. “Global Democracy Index 2019”. https://infographics. economist.com/2020/democracy-index-2019/map.html 
Fairclough, Isabela and Norman Fairclough. 2012. Political Discourse Analysis: $A$ Methods for Advanced Students. London: Routledge.

Fejérdy, Gergely. 2020. "Enlargement of the European Union in the Western Balkans from a French Perspective". In: Historical Experience and The Reunification of Europe, edited by IFAT, 30-54. Budapest: Institute for Foreign Affairs and Trade.

Financial Times. 2018. "Macron warns against hasty EU enlargement". https://www.ft.com/content/c09472ce-59cb-11e8-bdb7-f6677d2e1ce8

Foucher, Michel. 2016. “Where does Europe end?”, Le Monde Diplomatique, November 8. https://mondediplo.com/2016/11/08Europe

France Diplomacy. 2019. “France's strategy for the Western Balkans”. Accessed 25 February 2021. https://www.diplomatie.gouv.fr/en/country-files/europe/ western-balkans-62918/

Freedom House. 2020. "Freedom in the world 2020". https:/ / freedomhouse.org/ country/north-macedonia/freedom-world/2020

[FRSch] Foundation Robert Schuman. 2017. Emmanuel Macron's Europe - A vision, some proposals. European Issues No.445, October 27. https://www.robert-schuman.eu/en/european-issues/0445-emmanuelmacron-s-europe-a-vision-some-proposals

Gasmi, Gordana, and Dragan Prlja. 2020. "European path of the Western Balkans region-normative aspects and geopolitical factors". DOI: https://doi.org/ 10.18485/iup_rlr.2020.ch5

Haverluk, Terennce W., Kevin M. Beauchemin and Brandon A. Mueller. 2014. "The three critical flaws of critical geopolitics: Towards neo-classical geopolitics". Geopolitics 19 (1): 19-39.

[IE] Initiative for Europe. Speech by M. Emmanuel Macron, President of the French Republic. 2017, September 26. https://www.diplomatie.gouv.fr/ IMG/pdf/english_version_transcript_-_initiative_for_europe__speech_by_the_president_of_the_french_republic_cle8de628.pdf

[IFAT] Institute for Foreign Affairs and Trade. 2020. Historical Experience and the Reunification of Europe. Budapest. https://www.academia.edu/44681532/ Historical_Experience_and_the_Reunification_of_Europe_Foreign_Policy_Re view_Special_Volume.

Kelly, Phil. 2006. "A critique of critical geopolitics". Geopolitics 11 (1): 24-53.

Ker-Lindsay, J., Ioannis Armakolas, Rosa Balfour and Corina Stratulat 2017. "The national politics of EU enlargement in the Western Balkans". Southeast European and Black Sea Studies 17 (4): 511-522.

Kissinger, Henry. 1994. Diplomacy. New York: Simon \& Schuster. 
Lalatović, Bojana. 2020. "The new methodology of negotiating with the candidate countries in the context of Macron's reshaping of European Union". EU and Comparative Law Issues and Challenges Series (ECLIC) 4: 379-402.

Le Grand Continent. 2020. "La doctrine Macron: une conversation avec le Président français" November 16. https://legrandcontinent.eu/fr/2020/11/16/ macron/

Mamadouh, Virginie D. 1998. "Geopolitics in the nineties: one flag, many meanings". Geojournal 46 (4): 237-253.

O’Tuathail, Gerard and John Agnew. 1992. "Geopolitics and discourse: Practical geopolitical reasoning in American foreign policy". Political Geography 11 (2): 190-204.

O’Tuathail, Gerard. 1996. Critical Geopolitics. London: Routledge.

O’Tuathail, Gerard and Simon Dalby. 1998. Rethinking geopolitics. London: Routledge.

O’Tuathail, Gerard, Simon Dalby and Paul Routledge, eds. 1998. The geopolitics reader. London and New York: Routledge.

O’Tuathail, Gerard. 1999. "Understanding Critical Geopolitics: Geopolitics and Risk Society”. The Journal of Strategic Studies 22 (2-3): 107-124.

Pellet, Alain. 1992. "The Opinions of the Badinter Arbitration Committee A Second Breath for the Self-Determination of Peoples". Eur. J. Int'l L. 3: 178-185.

Plevák, Ondřej. 2021. "Michal Vít: Rozšiřování skončilo, do roku 2030 se celá EU změní”, Euractiv, January 22. https://euractiv.cz/section/rozsirenieu/interview/michal-vit-rozsirovani-skoncilo-do-roku-2030-se-cela-eu-zmeni/

Politico. 2019. "Non-Paper Reforming the European Union accession process" November. https://www.politico.eu/wp-content/uploads/2019/11/Enlargement-nonpaper.pdf

Reclus, Elisée. 1908. L'Homme et la Terre (1905-1908). Paris: Librairie universelle.

Smith, Karen E. 2017. "Enlargement, the neighbourhood, and European order". International relations and the European Union: 316-326.

Walldén, Axel Sotiris. 2017. "The demise of EU enlargement policy". http://www.eliamep.gr/wp-content/uploads/2017/03/Enlargement-policy1701-fin.pdf

Wunsch, Natasha. 2017. "Between indifference and hesitation: France and EU enlargement towards the Balkans". Southeast European and Black Sea Studies 17 (4): 541-554. 


\section{GEOPOLITIČKA VIZIJA FRANCUSKE \\ ZA EVROPU I ZAPADNI BALKAN: SLUČAJ SEVERNE MAKEDONIJE}

Apstrakt. Cilj ovog rada je da analizira položaj Francuske u globalnom i regionalnom geopolitičkom kontekstu. To takođe podrazumeva i njen odnos u vezi sa politikom proširenja EU i njenog pogleda na Zapadni Balkan i Severnu Makedoniju. Sama Evropska unija je zasnovana na širenju demokratskih vrednosti i ekonomskih koristi za članice. Takođe, EU je nedavno razvila i održive politike susedstva. No, nedavni događaji poput Bregzita, nesporazumi u Uniji i blokada procesa proširenja doveli su do dekonstruktivnih procesa i otvorili nova pitanja koja zahtevaju sveobuhvatnu naučnu analizu. Cilj rada je geopolitička analiza Francuske i njenog uticaja na Zapadni Balkan i politiku proširenja EU. Promena metodologije približavanja EU zaustavila je istoimeni proces za Severnu Makedoniju i Albaniju u 2019. godini. Pokušaćemo da istražimo i pružimo rešenje za Severnu Makedoniju, uzimajući u obzir novi aspekt njene spoljne politike i moguću ulogu Francuske u tom procesu. Sa teorijskog stanovišta, ovaj rad se zasniva na kritičkoj geopolitici, tj. na praktičnom geopolitičkom pristupu.

Kjučne rečr: Francuska, geopolitika, Severna Makedonija, Zapadni Balkan.

received: 28.01 .2021

accepted: 15.03 .2021 